Fakultas Hukum Universitas Lancang Kuning, Jalan Yos Sudarso KM 8 Rumbai Pekanbaru, Riau,

Kode Pos 28266. Telp: (+62761)-51877

E-mail: jurnal.respublica@ac.id

Website: https://journal.unilak.ac.id/index.php/Respublica

\title{
Tanggung Jawab Hukum Perusahaan Asuransi Jiwa terhadap Tertanggung dalam Pembayaran Klaim Asuransi
}

\author{
Indra Afrita ${ }^{\mathrm{a}}$, Wilda Arifalina ${ }^{\mathrm{b}}$ \\ ${ }^{a}$ Fakultas Hukum, Universitas Lancang Kuning, Pekanbaru, Indonesia, Email: indra_afrita@yahoo.com \\ ${ }^{\mathrm{b}}$ Fakultas Hukum, Universitas Lancang Kuning, Pekanbaru, Indonesia, Email: wilda2rifalina@gmail.com
}

Article Info

\section{Article History:}

Received : 21-01-2021

Revised : 20-02-2021

Accepted : 20-03-2021

Published : 28-05-2021

\section{Keywords:}

Keyword 1 : Liability Keyword Keyword 2 : Life Insurance company

Keyword 3 : Insurad Claim

\begin{abstract}
How is the Legal Liability of the Life Insurance Company to the Insured in Payment of Insurance Claims. The type of research carried out is normative law, which is library research whose data is obtained from reviewing library materials. The results and discussion of the research are the legal responsibility of the life insurance company to the insured in payment of insurance claims where the life insurance agreement called the policy is valid if it has been closed (there has been a conformity of will) based on these provisions the payment of compensation to the policyholder or appointed must be carried out by the insurer if an event or risk has occurred. Legal settlements carried out by life insurance companies against the insured in payment of insurance claims in the event of bankruptcy of the Insurance Company, guarantees of protection for insurance policy holders have been strictly regulated by policy holders to get paid off first than other creditors
\end{abstract}

\section{Informasi Artikel}

\section{Histori Artikel:}

Diterima : 21-01-2021

Direvisi : 20-02-2021

Disetujui : 30-03-2021

Diterbitkan : 28-05-2021

\section{Kata Kunci:}

Kata Kunci 1 : Tanggung

Jawab

Kata Kunci 2 : Perusahaan

Asuransi Jiwa

Kata Kunci 3 : Klaim

\begin{abstract}
Abstrak
Bagaimana Tanggung Jawab Hukum Perusahaan Asuransi Jiwa terhadap Tertanggung dalam Pembayaran Klaim Asuransi. Jenis penelitian yang dilakukan adalah hukum normatif merupakan penelitian kepustakaan yang datanya diperoleh dari mengkaji bahan-bahan pustaka. Hasil dan pembahasan dari penelitian adalah Tanggung jawab hukum perusahaan asuransi jiwa terhadap tertanggung dalam pembayaran klaim asuransi dimana perjanjian asuransi jiwa yang disebut dengan polis berlaku apabila telah ditutup (telah ada persesuaian kehendak) berdasarkan ketentuan tersebut pembayaran uang santunan kepada pemegang polis atau tertunjuk wajib dilaksanakan oleh penanggung apabila telah terjadi evenemen atau resiko. Penyelesaian hukum yang dilakukan oleh perusahaan asuransi jiwa terhadap tertanggung dalam pembayaran klaim asuransi dalam hal kepailitan Perusahaan Asuransi, jaminan perlindungan terhadap pemegang polis asuransi telah diatur secara tegas pemegang polis mendapatkan pelunasan terlebih dahulu dari pada kreditur lainnya.
\end{abstract}




\section{PENDAHULUAN}

Pembangunan ekonomi memerlukan dukungan investasi dalam jumlah yang memadai yang pelaksanaannya harus berdasarkan kemampuan sendiri. Oleh karena itu diperlukan usaha yang sungguh-sungguh untuk mengerahkan dana investasi, khususnya yang bersumber dari tabungan masyarakat. Usaha perasuransian sebagai salah satu lembaga keuangan menjadi penting, karena kegiatan usaha ini diharapkan dapat meningkat lagi pengerahan dana masyarakat untuk pembiayaan pembangunan. Dalam pada itu, pembangunan tidak luput pula dari berbagai resiko yang dapat mengganggu hasil pembangunan yang telah tercapai. Sehubungan dengan itu dibutuhkan hadirnya usaha perasuransian yang tangguh, yang dapat menampung kerugian yang dapat timbul oleh adanya berbagai resiko. Kebutuhan akan jasa perasuransian juga merupakan salah satu sarana finansial dalam tata kehidupan ekonomi rumah tangga, baik dalam menghadapi resiko finansial yang timbul sebagai akibat dari resiko yang paling mendasar, yaitu resiko alamiah datangnya kematian maupun dalam menghadapi berbagai resiko atas harta benda yang dimiliki, ${ }^{1}$ sebenarnya tidak ada yang menginginkan resiko terjadi yang menyebabkan kerugian pada masing-masing pihak tersebut, oleh karena itu manusia selalu berusaha untuk mencegahataupun menanggulangi resiko yang kemungkinan terjadi. Usaha menanggulangi resiko tersebut bisa diatasi apabila terjadi resiko yang tidak diinginkan.

Penanggulangan resiko oleh pihak asuransi dilakukan melalui suatu perjanjian khusus yang dilakukan untuk menanggulangi resiko yang sering disebut dengan perjanjian pertanggungan. ${ }^{2}$ Sesuai konsepnya asuransi pada prinsipnya adalah peralihan resiko. Dalam hal ini ada peralihan resiko dari si pemegang polis atau nasabah kepada pihak perusahaan asuransi, dimana pemegang polis atau nasabah wajib membayar premi asuransi sesuai kesepakatan asuransi untuk memberikan penggantian kepada tertanggung bila terjadi suatu evenemen atau kerugian. Program yang diadakan oleh pihak penanggung yaitu perusahaan asuransi cukup mempengaruhi meningkatnya jumlah pemegang polis

\footnotetext{
${ }^{1}$ Junaedy Ganie, Hukum Asuransi di Indonesia, (Jakarta: Sinar Grafika,2013), hlm. 44.

2 Abdulkadir Muhammad, Hukum Asuransi Indonesia, (Jakarta: Citra Aditya Bakti,1999), hlm. 166.
} 
di Indonesia. Apalagi saat ini banyak perusahaan asuransi berlomba-lomba menawarkan berbagai produk-produk asuransi yang tujuannya untuk menarik minat masyarakat berasuransi. Banyaknya produk yang diatawarkan oleh perusahaan asuransi tidak disertai dengan jaminan perlindungan hukum terhadap pemegang polis asuransi. Kebutuhan akan hadirnya usaha perasuransian juga dirasakan oleh dunia usaha, mengingat disatu pihak terdapat berbagai risiko (Sri Rejeki Hartono; 2001;1) yang secara sadar dan rasional dirasakan dapat mengganggu kesinambungan kegiatan usahanya, dilain pihak dunia usaha seringkali tidak dapat menghindarkan diri dari suatu sistem yang memaksanya untuk menggunakan jasa usaha perasuransian. ${ }^{3}$ Usaha perasuransian telah cukup lama hadir dalam perekonomian Indonesia dan berperan dalam perjalanan sejarah bangsa berdampingan dengan sektor kegiatan lainnya. Sementara itu usaha asuransi merupakan usaha yang menjanjikan perlindungan kepada pihak tertanggung dan sekaligus usaha itu juga menyangkut dana masyarakat. ${ }^{4}$ Dengan kedua peranan usaha asuransi tersebut, dalam perkembangan ekonomi semakin meningkat maka semakin terasa kebutuhan akan hadirnya industri perasuransian yang kuat dan dapat diandalkan .

Bisnis asuransi adalah bisnis yang mengumpulkan dana dari masyarakat banyak, yang selanjutnya digunakan dan dikelola sementara oleh perusahaan asuransi sebagai imbalan dari peralihan resiko di dalam perjanjian pertanggungan yang umumnya di investasikan lagi dalam sistim pembiayaan atau ke pasar modal oleh perusahaan asuransi tersebut. ${ }^{5}$ Bisnis ini sangat mengandalkan kepercayaan untuk melindungi dan untuk memastikan bahwa masyarakat sebagai pemegang polis Pasal 53 ayat (1) UU perasuransian telah mengatur: perusahaan asuransi dan perusahaan asuransi syariah wajib menjadi peserta program penjaminan polis, melihat kondisi ekonomi yang tidak menguntungkan akhir meyebabkan perusahaan tidak dapat melaksanakan kewajibannya dalam membayar ganti

\footnotetext{
${ }^{3}$ Sri Rejeki Hartono, Hukum Asuransi Dan Perusahaan Asuransi, (Jakarta : Sinar Grafika, 2001), hlm. 1.

4 Soesno Djojosoedarso, Hukum Asuransi Dan Perusahaan Asuransi, ( Jakarta : Sinar Grafika,2003) hlm. 73

${ }^{5}$ Djoko Prakoso dan I Ketut Murtika, Hukum Asuransi Indonesia, (Jakarta: Bina Aksara,2010), hlm. 18.
} 
kerugian/ klaim akibat terjadinya resiko terhadap pihak tertanggung pada akhirnya yang paling terutama bagi pemegang polis perusahaan asuransi pailit memunculkan permasalahan terhadap dana milik mereka/ tertanggung tidak dapat kembali utuh. ${ }^{6}$ Persoalannya bahwa pada umumnya jangka waktu perlindungan asuransi yang disepakati adalah dengan tenggang waktu yang relatif cukup lama . Kita tidak tahu apa yang akan terjadi terhadap perusahaan asuransi tersebut pada jangka waktu lima tahun, sepuluh tahun atau bahkan dua puluh tahun ke depan merupakan keniscayaan bahwa disebabkan satu dan lain hal, suatu perusahaan asuransi di kemudian hari dapat dinyatakan pailit melalui proses peradilan, atau dilikuidasi oleh badan/lembaga yang berwenang menurut hukum. Putusan pengadilan yang menyatakan suatu perusahaan asuransi pailit akan sangat berdampak kepada seluruh tertanggung pada perusahaan asuransi dimaksud. Premi para tertanggung baik yang belum jatuh tempo maupun yang telah jatuh tempo saat perusahaan asuransi dimaksud dinyatakan pailit harus dilindungi oleh hukum. Sehubungan dengan memerlukan pembinaan dan pengawasan secara berkesinambungan dari Pemerintah dalam rangka pengamanan kepentingan masyarakat.

Usaha perasuransian merupakan usaha yang menjanjikan perlindungan hukum kepada pihak tertanggung dan juga dana dari masyarakat . Selanjutnya perusahaan perasuransian wajib memelihara usaha yang sehat. Namun dalam perkembangannya, perusahaan asuransi tidak dapat melaksanakan usahanya dan kewajiban sebagaimana ditentukan dalam undang-undang, diantaranya masalah kekayaaan perusahaan yang tidak mendukung pertumbuhan perusahaan asuransi. ${ }^{7}$ Dengan demikian tentunya perusahaan asuransi dapat dinyatakan pailit, kepailitan mengatur sita umum atas semua kekayaan debitur Pailit yang pengurusan dan pemberesannya dilakukan oleh Kurator di bawah pengawasan hakim pengawas sebagaimana dimuat dalam Undang-Undang No 37 tahun 2004 tentang Kepailitan dan Penundaan Kewajiban Pembayaran Utang yang selanjutnya ditulis UndangUndang Kepailitan ini masih membuka peluang untuk mempailitkan perusahaan

\footnotetext{
${ }^{6}$ Emmy Pangaribuan Simanjuntak, Hukum Pertanggungan, Seksi Hukum Dagang, (Yogyakarta: Fakultas Hukum U,niversitas Gadjah Mada, 1980), hlm 75.

${ }^{7}$ Gatot Supramono, Perjanjian Utang-Piutang, (Jakarta: Prenadamedia Group, 2013), hlm. 10.
} 
asuransi. Berdasarkan UU Kepailitan ini permohonan pernyataan pailit terhadap perusahaan asuransi, perusahaan reasuransi, dana pensiun, atau Badan Usaha Milik Negara yang bergerak di bidang kepentingan publik, hanya dapat diajukan oleh Menteri Keuangan. Akan tetapi selanjutnya berdasarkan Undang-Undang Nomor 21 tahun 2011 tentang Otoritas Jasa Keuangan yang selanjutnya ditulis OJK pada Pasal 55 ayat (1) diatur sejak tanggal 31 Desember 2012, fungsi, tugas, dan wewenang pengaturan dan pengawasan kegiatan jasa keuangan di sektor Pasar Modal, Perasuransian, Dana Pensiun, Lembaga Pembiayaan, dan Lembaga Jasa Keuangan Lainnya beralih dari Menteri Keuangan dan Badan Pengawas Pasar Modal dan Lembaga Keuangan ke Otoritas Jasa Keuangan.

Peralihan kewenangan ini kemudian dipertegas lagi berdasarkan UndangUndang Nomor 40 Tahun 2014 tentang Perasuransian pada Pasal 50 ayat (1) memuat: permohonan pernyataan pailit terhadap perusahaan asuransi, perusahaan asuransi syariah, perusahaan reasuransi, atau perusahaan reasuransi syariah berdasarkan Undang-Undang ini hanya dapat diajukan oleh Otoritas Jasa Keuangan. Tertanggung dalam kondisi serba tidak adanya kepastian terhadap hakhak mereka serta dalam kecemasan mencari tempat mengadu atas kerugian yang mereka tanggung. Namun OJK sebagai lembaga pengawas industri keuangan dan jasa asuransi terus bungkam atas kejadian tersebut. Kasus gagal bayar tersebut terjadi pada perusahaan-perusahaan asuransi besar, kondisi yang membuat harapan publik terhadap industri asuransi pupus. Paling baru terjadi yakni dengan PT Bumi Asih Jaya, PT Asuransi Jiwasraya (Persero), Asuransi Jiwa Bersama Bumi Putra 1912 menambah deretan kasus gagal bayar asuransi jiwa di Indonesia setelah sebelumnya dialami nasabah, berikut beberapa kerugian tertanggung gagal bayar asuransi yang ditetapkan oleh OJK antara lain adalah: PT kresna Life kerugian sebesar Rp 6,4 Miliyar, PT Jiwasraya kerugian sebesar Rp 16 Miliyar, PT Bakrie Life kerugian sebesar Rp 500 Miliyar, PT Bumi Asih Jaya kerugian sebesar Rp 1,4 Miliyar dan AJB Bumi Putera 1912 kerugian sebesar 20 Miliyar.

Dalam masyarakat yang sudah maju dan sadar akan nilai kegunaan lembaga asuransi atau pertanggungan sebagai lembaga pelimpahan risiko, setiap kemungkinan terhadap bahaya menderita kerugian itu pasti diasuransikan atau 
dipertanggungkan. Hampir setiap gerak dan aktivitas baik pribadi atau badanbadan usaha itu selalu dilindungi oleh suatu perjanjian pertanggungan yang mereka adakan, atau dengan perkataan lain setiap kemungkinan risiko itu selalu dipertanggungkan jadi semakin orang merasa makin tidak aman, semakin pula orang selalu berusaha mengasuransikan segala kemungkinan risiko yang mungkin timbul makin banyak yang merasa tidak aman makin banyak yang mengalihkan risiko kepada pihak lain, berarti makin banyak perjanjian asuransi ditutup. Selanjutnya makin banyak pula dana yang diserap oleh perusahaan sebagai pembayaran atas kesedianya mengambil alih risiko pihak tertanggung, menurut Satijipto Raharjo perlindungan hukum adalah memberikan pengayoman terhadap hak asasi manusia yang dirugikan orang lain dan perlindungan itu diberikan kepada masyarakat agar dapat menikmati semua hak-hak yang diberikan oleh hukum. ${ }^{8}$ Dalam usaha memberikan keamanan di tempat kita berada peran aparat penegak hukum yang dibantu oleh sektor keamanan lain tidaklah cukup. Peran swasta seperti asuransi sangatlah berperan dalam mewujudkan keamanan tersebut

Berdasarkan uraikan di atas, penelitian ini mecoba membahas tentang tanggung jawab hukum perusahaan asuransi jiwa terhadap tertanggung dalam pembayaran klaim asuransi. Serta penyelesaian hukum yang dilakukan oleh perusahaan asuransi jiwa terhadap tertanggung dalam pembayaran klaim asuransi.

Jenis penelitian ini adalah; penelitian hukum normatif/ yuridis normative yakni penelitian hukum normatif merupakan penelitian kepustakaan yang datanya diperoleh dari mengkaji bahan-bahan pustaka. Penelitian ini mengacu pada norma-norma hukum yang didapat dalam putusan-putusan pengadilan, norma-norma hukum yang ada dalam masyarkat, maupun dalam peraturan perundang-undangan.

\section{HASIL DAN PEMBAHASAN}

Dalam perjalanan hidup manusia tentu saja selalu dihadapkan pada suatu resiko yang akan terjadi dan tidak bisa diprediksi atau peristiwa yang tidak diketahui sebelumnya. Dalam menghadapi dan mengantisipasi kemungkinan yang

\footnotetext{
${ }^{8}$ Satijipto Raharjo, Permasalahan hukum di Indonesia, (Bandung: alumni,2000).
} 
akan terjadi tersebut, maka seyogyanya manusia berusaha untuk dapat memperkecil resiko dengan jalan mengalihkan resiko tersebut kepada pihak lain. Pelimpahan risiko ini dapat dilakukan dengan cara melakukan perjanjian antara pihak tertanggung dengan penanggung. ${ }^{9}$ Pengertian asuransi menurut ahli adalah suatu perjanjian consensueel dianggap telah terjadi manakala telah tercapai kata sepakat antara kedua pihak. ${ }^{10}$ Meskipun demikian, undang-undang memerintahkan dibuatnya suatu akte di bawah tangan yang dinamakan polis, dengan maksud untuk memudahkan pembuktian jika terjadi perselisihan, pengaturan hak dan kewajiban para pihak dalam perjanjian asuransi jiwa dalam pasal 255 KUHD disebutkan bahwa: "suatu pertanggungan harus dibuat secara tertulis dalam suatu akta yang dinamakan polis.” Ketentuan tersebut memberikan kesan seolah-olah perjanjian asuransi jiwa harus dibuat secara tertulis sebagai syarat mutlak. Padahal polis bukanlah syarat mutlak adanya perjanjian asuransi jiwa, tetapi hanyalah merupakan alat bukti adanya perjanjian.

\section{Tanggung jawab hukum perusahaan asuransi jiwa terhadap tertanggung dalam pembayaran klaim asuransi}

Perjanjian asuransi mempunyai tujuan bahwa pihak yang mempunyai kemungkinan menderita risiko kerugian (pihak tertanggung) melimpahkan kemungkinan kemungkinan dari risiko kerugian yang terjadi kepada pihak lain yang bersedia membayar ganti rugi (pihak penanggung), dan akte tersebut berguna menjadi pembuktian untuk salah satunya prihal suatu Perusahaan Asuransi mengalami kepailitan, perjanjian asuransi jiwa berlaku apabila telah ditutup (telah ada persesuaian kehendak) dalam hal ini berarti bahwa walaupun tidak ada polis (polis belum terbit) telah melaksanakan hak dan kewajiban dan dapat dibutikan dengan bukti-bukti lain, misalnya dengan kwitansi pembayaran premi. Dalam perjanjian asuransi jiwa para pihak yaitu pemegang polis, penanggung dan tertunjuk (penikmat asuransi) mempunyai hak dan kewajiban masing-masing yang bersifat timbal balik dimana hak dan kewajiban pemegang

\footnotetext{
${ }^{9}$ Wirjono Prodjodikoro, Hukum Asuransi di Indonesia, (Jakarta; PT Intermasa, 1981), hlm. 4.

${ }^{10}$ Subekti, Pokok-Pokok Hukum Perdata, (Jakarta: Intermasa, 2003), hlm. 219.
} 
polis sebaliknya juga merupakan hak dan kewajiban perusahaan asuransi sebagai penanggung.

Adapun hak dan kewajiban yang dimaksud antara lain sebagai berikut:

a. Hak-hak dari pemegang polis antara lain: 1). hak untuk mendapatkan ganti kerugian apabila terjadi evenemen. Menurut Pasal 1 ayat (1) (huruf b) UU No. 40 Tahun 2014 menyatakan: “memberikan pembayaran yang didasarkan pada meninggalnya tertanggung atau pembayaran yang didasarkan pada hidupnya tertanggung dengan manfaat yang besarnya telah ditetapkan dan/atau didasarkan pada hasil pengelolaan dana." Berdasarkan ketentuan tersebut pembayaran uang santunan kepada pemegang polis atau tertunjuk wajib dilaksanakan oleh penanggung apabila telah terjadi evenemen (meninggalnya tertanggung) sebagai timbal balik atas premi yang dibayarkan oleh pemegang polis. 2). Hak untuk mendapatkan jumlah pertanggungan apabila tidak terjadi evenemen dalam masa asuransi. Pada masa asuransi jiwa berakhir tanpa terjadi evenemen, pemegang polis atau tertunjuk berhak mendapatkan pengembalian sejumlah uang tertentu dari penanggung sesuai dengan perjanjian dalam polis.

b. kewajiban-kewajiban dari pemegang polis atau tertanggung antara lain: 1). Kewajiban membayar premi kepada penanggung. Ketentuan mengenai kewajiban membayar premi bagi pemegang polis asuransi kepada penanggunng diatur dalam Pasal 246 KUHD dan Pasal 1 ayat (1) UU Peransuransian. Premi merupakan kewajiban pemegang polis untuk membayarnya kepada penanggung sebagai kontraprestasi dari ganti kerugian atau uang santunan yang akan penanggung berikan padanya, premi merupakan syarat esensial dalam perjanjian asuransi.

2). Kewajiban untuk memberikan keterangan-keterangan yang diperlukan oleh penanggung dengan iktikad baik. Adanya ketentuan yang mewajibkan kepada pemegang polis supaya memberitahukan tentang keadaan objek yang akan diasuransikannya dengan dilandasi iktikad baik 


\section{Penyelesaian hukum yang dilakukan oleh perusahaan asuransi jiwa terhadap tertanggung dalam pembayaran klaim asuransi}

Dalam hal kepailitan Perusahaan Asuransi, jaminan perlindungan terhadap pemegang polis asuransi telah diatur secara tegas dalam UU No. 40 Tahun 2014 Tentang Peransuransian ketentuan Pasal 52 ayat (1) UU Peransuransian, kedudukan para pemegang polis asuransi dalam memperoleh pembayaran piutang menjadi tegas yaitu pemegang polis berkedudukan sebagai kreditur preferen yang artinya dalam pembagian harta kekayaan, pemegang polis mendapatkan pelunasan terlebih dahulu dari pada kreditur lainnya. Menurut ketentuan Pasal 52 ayat (2) UU Peransuransian, dana asuransi yaitu kumpulan dana yang berasal dari premi yang dibentuk untuk memenuhi kewajiban yang timbul dari polis yang diterbitkan atau dari klaim asuransi. Ketika perusahaan asuransi dipailitkan maka pembagian dana asuransi harus digunakan terlebih dahulu untuk memenuhi kewajiban pembayaran klaim kepada pemegang polis yang berhak atas manfaat asuransi.

Dalam ketentuan Pasal 52 ayat (1) dan (2) UU Kepailitan tersebut, memuat dalam hal terjadi kepailitan pada perusahaan asuransi ini pemegang polis yang berhak atas manfaat asuransi dijamin dengan polis asuransi yang mana pada isi polis tersebut telah memuat banyak hal terkait pelaksanaan hak dan kewajiban terutama mengenai pembayaran ganti kerugian dan pembayaran sejumlah uang kepada pemegang polis. Bila merujuk pada ketentuan di atas jelaslah bahwa UU Peransuransian dan polis asuransi telah memberikan perlindungan hukum yang tegas dan jelas karena telah menempatkan pemegang polis pada kedudukan yang lebih tinggi dari pada pihak lain yaitu sebagai kreditur istimewa (preferen) dalam hal memperoleh pelunasan piutang pada mekanisme pembagian harta kekayaan perusahaan asuransi yang pailit. Hal ini sejalan dengan ketentuan dalam polis asuransi jiwa yang tertuang pada syarat-syarat umum polisnya bahwa pembayaran manfaat asuransi kepada pemegang polis harus segera dilakukan setelah pemegang polis mengajukan klaim.

Hal ini sejalan dengan asas hukum yang berlaku, yakni asas lex specialis derogat lex generalis, di mana ketentuan Pasal 52 ayat (1) dan (2) UU Peransuransian sebagai ketentuan atau aturan hukum khusus harus dikedepankan 
pelaksanaannya dengan cara mengabaikan (mengenyampingkan) ketentuan hukum umum yang tertuang dalam UU Kepailitan, karena UU Peransuransian sendiri secara khusus telah mengatur dan menempatkan kedudukan pemegang polis secara tegas sebagai kreditur yang diutamakan atau didahulukan pembayaran hak-haknya (preferen). Namun perlu diingat bahwa kedudukan pemegang polis yang dimaksud di atas tentu saja sebagai kreditur preferen yang istimewa (privilege), bukan kreditur preferen yang separatis, karena pemegang polis bukan pemegang jaminan kebendaan seperti, gadai, hipotik, atau fidusia. Jadi ketentuan KUHPerdata dan UU Kepailitan harus tunduk kepada ketentuan Pasal 52 ayat (1) dan (2) UU Peransuransian bila terjadi kepailitan suatu perusahaan asuransi.

Upaya hukum yang dapat ditempuh pemegang polis apabila perusahaan asuransi dinyatakan pailit oleh Pengadilan Niaga untuk mendapatkan hak-haknya berupa pembayaran dari piutangnya, ${ }^{11}$ yaitu pemegang polis asuransi dapat menuntut hak yang menyangkut harta pailit dengan mengajukan klaim asuransi kepada kurator yang tata caranya sama seperti pengajuan klaim pada perusahaan asuransi karena adanya pernyataan pailit oleh Pengadilan Niaga atas permohonan Otoritas Jasa Keuangan mengakibatkan segala hak dan kewajiban perusahaan asuransi untuk melaksanakan perjanjian menurut ketentuan Pasal 50 ayat (1) UU Peransuransian dan ketentuan dalam polis asuransi telah diambil alih oleh kurator. Setelah adanya putusan pailit dari Pengadilan Niaga, kurator akan menentukan pembagian pembayaran utang-utang Debitur pailit kepada Kreditur menurut besar kecilnya jumlah piutang masing-masing. Pembayaran utang-utang tersebut akan dibayar menurut kedudukannya berdasarkan sifat piutang masing-masing Kreditur, baik Kreditur preferen, Kreditur konkuren, maupun Kreditur separatis.

\section{KESIMPULAN}

Berdasarkan dari hasil pembahasan di atas, maka penulis dapat menarik suatu simpulan sebagai berikut:

\footnotetext{
${ }^{11}$ Ketut Artadi, Anatomi Kontrak Berdasarkan Hukum Perjanjian, (Jakarta: Udayana University Press, 2014), hlm. 32.
} 
1).Tanggung jawab hukum perusahaan asuransi jiwa terhadap tertanggung dalam pembayaran klaim asuransi dimana perjanjian asuransi jiwa yang disebut dengan polis berlaku apabila telah ditutup (telah ada persesuaian kehendak) dalam perjanjian asuransi jiwa para pihak yaitu pemegang polis, penanggung dan tertunjuk (penikmat asuransi) mempunyai hak dan kewajiban masingmasing yang bersifat timbal balik dimana hak dan kewajiban pemegang polis sebaliknya juga merupakan hak dan kewajiban perusahaan asuransi sebagai penanggung. Berdasarkan ketentuan tersebut pembayaran uang santunan kepada pemegang polis atau tertunjuk wajib dilaksanakan oleh penanggung apabila telah terjadi evenemen atau resiko.

2). Penyelesaian hukum yang dilakukan oleh perusahaan asuransi jiwa terhadap tertanggung dalam pembayaran klaim asuransi dalam hal kepailitan Perusahaan Asuransi, jaminan perlindungan terhadap pemegang polis asuransi telah diatur secara tegas dalam UU No. 40 Tahun 2014 Tentang Peransuransian ketentuan Pasal 52 ayat (1) UU Peransuransian, kedudukan para pemegang polis asuransi dalam memperoleh pembayaran piutang menjadi tegas yaitu pemegang polis berkedudukan sebagai kreditur preferen yang artinya dalam pembagian harta kekayaan, pemegang polis mendapatkan pelunasan terlebih dahulu dari pada kreditur lainnya.

\section{DAFTAR PUSTAKA}

Abdulkadir Muhammad, 1999, Hukum Asuransi Indonesia, Jakarta: Citra Aditya Bakti.

Djoko Prakoso dan I Ketut Murtika, 2010, Hukum Asuransi Indonesia. Jakarta: Bina Aksara .

Emmy Pangaribuan Simanjuntak, 1980 Hukum Pertanggungan, Seksi Hukum Dagang Fakultas Hukum U,niversitas Gadjah Mada, Yogyakarta.

Gatot Supramono, 2013, Perjanjian Utang-Piutang, Jakarta; Prenadamedia Group Junaedy Ganie, 2013, Hukum Asuransi di Indonesia, Jakarta: Sinar Grafika 
Ketut Artadi, 2014, Anatomi Kontrak Berdasarkan Hukum Perjanjian, Jakarta; Udayana University Press

Maman Suparman Sastrawidjaja dan Endang, 2013, Hukum Asuransi, Perlindungan Tertanggung, Asuransi Deposito, Usaha Perasuransian. Bandung: Alumni.

Sri Rejeki Hartono, 2001, Hukum Asuransi Dan Perusahaan Asuransi. Jakarta : Sinar Grafika.

Soesno Djojosoedarso, 2003. Prinsip-prinsip Manajemen Risiko dan Asuransi. Jakarta: Salemba Empat.

Soetjipto Raharjo, 2014. Permasalahan hukum di Indonesia. Bandung: alumni.

Subekti, 2003, Pokok-Pokok Hukum Perdata, Jakarta; Intermasa.

Wirjono Prodjodikoro , 1981, Hukum Asuransi di Indonesia, Jakarta; PT Intermasa.

\section{Perundang-undangan}

Undang - Undang Republik Indonesia Nomor 40 Tahun 2014 Tentang Perasuransian

Undang - Undang Republik Indonesia Nomor 21 Tahun 2011 Tentang Otoritas Jasa Keuangan

Undang - Undang Republik Indonesia Nomor 37 Tahun 2004 Tentang Kepailitan Dan Penundaan Kewajiban Pembayaran Utang 